像温度, 現像速度を変化させ $\mathrm{G}$ 值カブリ, 比感度, 粒状 度を検討した。そ結果, フィルム RAR2496 と現像液 D-19の組合せが得られ，現在使用し良好である。

\section{2. 現像条件による希土類システムの相反則不軌につい}

$\tau$

熊本大学医学部附属病院中央放射線部

○洞田貫誠志・守部伸幸

熊本大学医療技術短期大学部，東田善治

希土類増感紙+オルソフィルムシステム（Lenex Mi$\operatorname{dium}+\mathrm{OHI})$ において, 現像処理温度の変化に上る相反 則不軌への影響を検討した。

現像温度は $33^{\circ} \mathrm{C}, 35^{\circ} \mathrm{C}, 37^{\circ} \mathrm{C}$ 変化させ現像処理した

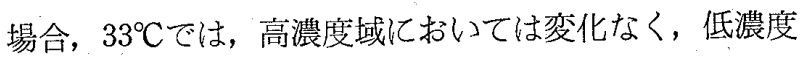

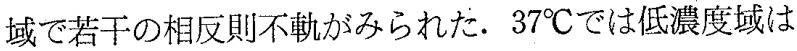
もとより, 高濃度域にも相反則不軌の現象がみられた。

結論として, 現像温度を高くするにしたがい，また， 曝射時間を長くすると，相反則不軌への影響が大きくな る. 今後希士類増感紙システムの使用がふえるととが予 想され，長時間撮影をするときとの影響が大きくなる.

座長集約 $(60 \sim 62)$

真栄城守侯（琉大病院）

この感光材料のセッションは発表演題数 3 題で, 演題 60 は 3 分 30 秒処理フィル $\Delta$ 製造中に伴ない，90秒処理 フィルムを 3 分 30 秒処理した場合どうなるかというとと の発表であった．演題61はシネアンギオ撮影の場合，心 㵴と肺野の境界部で読影に支障があるのでフィルム，現 像液を変えるととにより改善したとの発表であった。演 題62は高感度フィルムを使用した場合に，現像処理温度 による相反則不軌を論じたあのである，ただての場合夕 イムスケール法で特性曲線を作成しているので, 当然夕 イマの許容誤差が入って来るので, 短時間撮影の場合 (0.02秒等) は許容誤差内であ机ば, 誤差内として処理 してはどうか.

質問(61) 心藏，肺野の境界部分の濃度について質問 します。特性曲線上で $\curlyvee$ が濃度 1.5 以上になって，ねて 来ている.むしろ低濃度部のコントラストが問題であっ

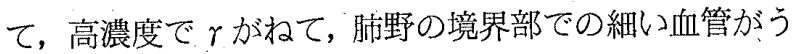
つるとは考えられない.

答 書き方がわるかったが，Dr．の学会発表のときに 印画紙にやきつけるときに，高コントラストではとんで しまう. シネフィルムの観察ではそれはど問題は生じな いが，印画紙にやきつける時にはコントラスを落したも のがほしい，そのための改良です．CFX の上うにロウ ○に落せばよいわけですが，心䁍全体を見る場合にはコ
ントラストがないと困るので，低濃度部のコントラスト を保ったまま肺野部のコントラストを落そうとしたのが 目的です.

\section{$\diamond$ 東京部会}

日 時 昭和57年 5 月 23 日(日)

場 所 関東聥信病院 7 階講堂

\section{会員研究発表}

1. 片面乳剂フィルムによる一般撮影系への忘用

立川共済病院

○竹内金枝・上遠野昭 杣沢 繁・中田好抒

$\mathrm{X}$ 線画質の改良は，種々の観点から研究がなされてい る. 一般に片面乳剤フィルムは一部の撮影系のみ使用さ れ, 両面乳剤フィルムよりX線画質は良いが感度は低 い. そこでわれわれ汸，数種の片面乳剤フィルムと希土 類増感紙をそれぞれ組合せ，どこまで感度を向上させる ことができるか検討したので報售する。

〔結論〕希土類増感紙 G-8, GTH, は片面乳郕フィル ム OM-1， と組合せるととにより，両面乳鼡システム

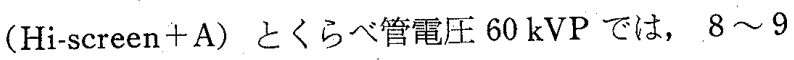
割, 管電圧 $80 \mathrm{kVP}$ で, 10 割以上の感度比を得るととが できる。

\section{2. 乳房撮影装置 CGR-500T による各種撮影手技の比} 較

癌研究会附属病院レントゲン診断部

○桑田祥萃・林 三樹 小倉敏裕・佐藤伸雄

〔結的】同一X線管を用いて, 低コントラスト微細被 検体の識別度を, コンサーブ撮影, グリッド撮影, 拡大 撮影の 3 種の術式について比較した。 それによって, 適 度な被曝線量で最大の情報を得る撮影術式の組み合せを 考えた。

〔組論〕（1)識別度では，拡大撮影が最む優れており， 次がグリッド撮影，コンサーブ撮影の順であった. 線量 では，拡大撮影が最む多く，グリッド撮影，コンサーブ 撮影の順であった。(2)理想的な術式の組み合せとして， ルチン検查では，グリッドを用いての全面撮影，また患 部が認められる例については，拡大スポット撮影が妥当 である。

\section{3. 正座位における膝蓋大腿関節撮影法の一考察} 昭和大学病院放射線部 ○成田久夫・荒木弘一 